\title{
Correction to: EndMT: New fndings on the origin of myofbroblasts in endometrial fbrosis of intrauterine adhesions
}

Chengcheng Xu, Meng Bao, Xiaorong Fan, Jin Huang, Changhong Zhu* and Wei Xia*

\section{Correction to: Reprod Biol Endocrinol 20, 9 (2022)}

https://doi.org/10.1186/s12958-022-00887-5

Following publication of the original article [1], the authors reported an error in Fig. 1. The panels "b, c and d" were misplaced in the image. The correct version of Fig. 1 is presented below.

The original article [1] has been updated.

Published online: 11 February 2022

\footnotetext{
Reference

1. Xu C, Bao M, Fan X, et al. EndMT: New findings on the origin of myofibroblasts in endometrial fibrosis of intrauterine adhesions. Reprod Biol Endocrinol. 2022;20:9. https://doi.org/10.1186/s12958-022-00887-5.
}

The original article can be found online at https://doi.org/10.1186/s12958022-00887-5.

*Correspondence: reprodcentre@163.com; tjxiawei@hust.edu.cn Institute of Reproductive Health, Tongji Medical College, Huazhong University of Science and Technology, Wuhan 430030, China original author(s) and the source, provide a link to the Creative Commons licence, and indicate if changes were made. The images or other third party material in this article are included in the article's Creative Commons licence, unless indicated otherwise in a credit line to the material. If material is not included in the article's Creative Commons licence and your intended use is not permitted by statutory regulation or exceeds the permitted use, you will need to obtain permission directly from the copyright holder. To view a copy of this licence, visit http://creativecommons.org/licenses/by/4.0/. The Creative Commons Public Domain Dedication waiver (http://creativeco mmons.org/publicdomain/zero/1.0/) applies to the data made available in this article, unless otherwise stated in a credit line to the data. 


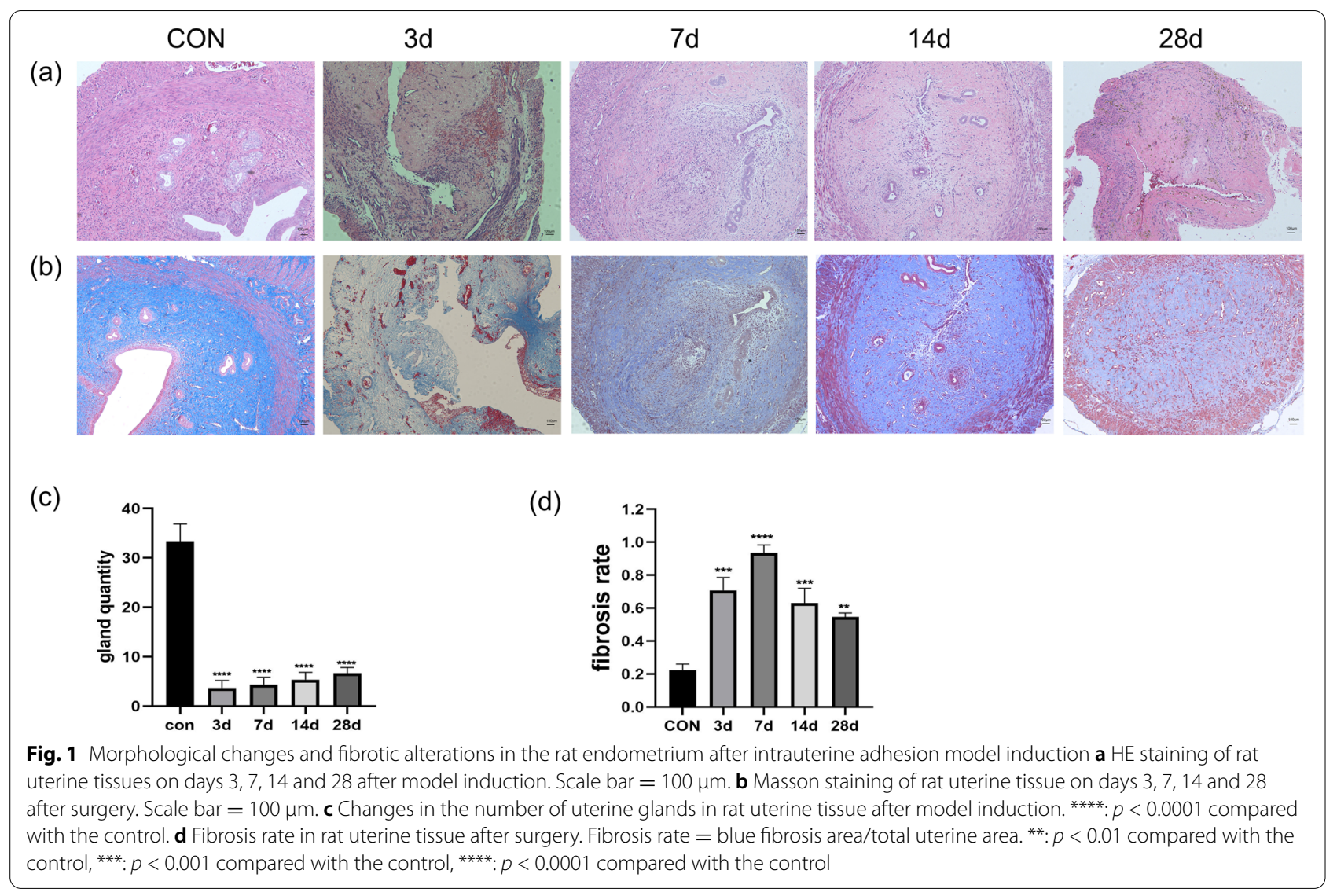

